\title{
Metrosexual Men in Thai Classical Literature
}

\author{
Orathai Piayura
}

\begin{abstract}
The recent trend on gender studies discusses the 'metrosexual' man as a new type of men in this decade. These categorized men are perceived as not being masculine. This article, however, illustrates that male bodies and beauty have been related since the olden days. In Thai classical literature, the warrior heroes behave like metrosexual men, as they are concerned about their bodies and beauty whilst being the role models of masculinity. Therefore, a metrosexual man is not a 'new type' of men, as he existed many centuries ago in Thai classical literature.
\end{abstract}

Index Terms-Men's bodies, metrosexual, thai literature.

\section{INTRODUCTION}

Since the mid 1980s, research on men and masculinities has grown quickly [1]. Interest in the study of men and masculinities across the disciplines has also increased in different countries worldwide [2]. Those theorists writing about men and masculinities from broad perspectives cover the topics of globalization, intimacy and the emotions, fatherhood, sport, violence, aging and the life course, the body, and so on [3]. Among these topics, the topic of "the body' has been one of the major concerns of academic study for the last twenty years, as it was confirmed by Kath Woodward (2008) that:

Over the last twenty years 'the body' has become a major concern of academic study... Body have also been central to activists' campaigns, especially those associated with 'identity politics,' many of which have focused on claiming rights over one's own body. People sought to take control over their own sexuality, reproductive rights, and to gain freedom from harassment and acts of racism and aggression. [4]

Men and women's bodies, therefore, have become the center of contemporary debate about the relevance of bodies and people's lives. However, it was, for general public observation, more common to illustrate women's bodies and relate them to the notion of beauty through various kinds of media and literature. Men's bodies and beauty, on the other hand, were not perceived as relevant because they were not socially constructed together to demonstrate 'masculinity,' as it was confirmed by Macan Ghaill (1996) that:

Masculinity has been seen to be constructed as the necessary counterpart to heterosexuality and so anything that does not fit into this pairing up of masculinity and heterosexuality becomes understood as being different [5].

Therefore, the emergence of 'metrosexual men' in 2002 was definitely seen as being something 'different.' Previously, the relationship between men's bodies and

Manuscript received March 9, 2013; revised April 30, 2013.

The authors are with the Department of Thai, Khon Kaen University Khon Kaen, Thailand (e-mail: orapan@kku.ac.th). beauty would lead to the assumption of those men as being gay or homosexual. Metrosexual men, however, defined themselves as men who were concerned about their beauty and appearance with no mentioning of their sexual preference. They confirmed that they were $100 \%$ heterosexual [6]. As metrosexual men could not fit into the traditional masculinity category, it led to the assumption that they were a new type of men emerging in this decade. Yet, men and their bodies were related to beauty since the olden times in Thai society; moreover, this phenomenon can be seen via many pieces of Thai classical literature.

\section{Metrosexual Man, New Man, AND Masculinity}

Robinson (2008) summarized that the study of men and masculinity by Edward (2006) can be divided into three main 'waves':

1) The 'first wave,' in the $1970 \mathrm{~s}$, refers to the development of the 'sex role' model in relation to questions surrounding masculinity.

2) The 'second wave,' in the $1980 \mathrm{~s}$, was based on the notion that the model of a white, western, and middle class account of masculinity was not adequate to explore the multifaceted nature of men's diverse experiences. Furthermore, the working class, black, and gay men were now viewed as subordinate to this hegemonic model, and importantly, the main emphasis in the study of masculinity was now on power and its very complex meanings and operations.

3) The 'third wave' since the $1990 \mathrm{~s}$ is very much influenced by the poststructuralist theory, in so much as it relates to performativity, normativity, and sexuality. In this phrase, Edward argues that we see a much more interdisciplinary body of work occurring, for instance, with work across literary, cultural, and media studies, as well as the social sciences. Here, the emphasis is now on masculinity as being contingent, open to change, and in flux [7].

This study of metrosexual men in Thai classical literature is, therefore, in the third wave as it is interdisciplinary and relates to 'performativity, normativity, and sexuality.' Abbott (1992) argued that socialization and the influence of biological factors, the media, language, and education formed masculinity. Different societies value different masculinities. However, masculinities changed throughout different periods of time and can be roughly divided into two categories: the traditional man and the new man.

The so-called traditional men are supposed to be:

1) Physical and aggressive

2) Not emotionally sensitive or self-revealing

3) Prefer the company of men

4) Develop strong male bonds but no intimacy

5) See marriage as a necessity, not romantic 
6) Believe in the domination of women

7) Have sexual double standards

8) See women as either good girls or bad girls

Contrary to the traditional men, the new men were supposed to be:

1) Economically well-off, intelligent, and have interpersonal skills

2) Emotionally sensitive and self expressive with women

3) Prefer the company of women

4) View heterosexual relationships as a source of support

5) See marriage as romantic

6) Believe in equal relationships

7) Have less of a sexual double standard

8) See women more as individuals [8]

Apart from possessing the above qualifications, some men in present society also have the beauty qualification and are being labeled as 'metrosexual' men. The term metrosexual was coined from the word 'metro' from 'metropolitan' and the word 'sexual' from 'heterosexual' to refer to men in cities who enjoy spending time and money on their bodies and clothes in order to maintain their good looks. This group of men paid special attention to their skin and bodies and spent money on cosmetics and products to take care of them. The metrosexual men claimed that they are $100 \%$ straight men, not gay or homosexual. They are men who just care about beauty. The following quote was the description of a metrosexual man by Mark Simpson:

Metrosexual man, the single young man with a high disposable income, living or working in the city (because that's where all the best shops are), is perhaps the most promising consumer market of the decade. In the Eighties he was only to be found inside fashion magazines such as GQ, in television advertisements for Levi's jeans or in gay bars. In the Nineties, he's everywhere and he's going shopping [9].

\section{Metrosexual Men in Thai Classical Literature}

In Thai literature, the notion of beauty has always been a central issue. Both male and female main characters have to be beautiful. Men and their bodies were presented together with beauty and were accepted in Thai 'cannon' literature. The following extract is an example of the presentation of male's beauty, cited from 'Lilit Pralor.'

The story is about two princesses who have heard about the beauty of a married prince and fall in love with him without seeing him. They try to make him aware of them and get him to come and meet them by means of magic. After the prince hears about the beauty of the two princesses, he too falls in love with them without seeing either princess. He then asks for permission from his mother and his wife to go to see them Neither his wife nor his mother wants him to go because these princesses are the daughters of an enemy king. However, nobody can stop the prince. He travels to meet the two princesses. In the end, the prince and princesses are all killed together on the orders of the princesses' grandmother, and the two kingdoms become friends. The following is the extract, which describes the beauty of the prince:

\section{รอยรูปอินทรหยาดฟ้า มาอ่าองค์ในหล้า}

แหล่งให้คนชม

แลฤา
พระองค์กลมกล้องแกล้ง

เอวอ่อนอรอันแท่ง

ถ้วนแห่งเจ้ากูงาม บารนี

โฉมผจญสามแผ่นแพ้

งามเลิศงามล้วนแล้

รูปต้องติดใจ

บารนี

ลือเขจรในแหล่งหล้า

ทุกทั่วคนเที่ยวค้า

เล่าล้วนยอโฉม

ท่านแล

เดือนจรัสโพยมแจ่มฟ้า

ผิว์บ่ได้เห็นหน้า

ลอราช ไซร้ดูเดือน

ดุจแล

ตาเหมือนตามฤคมาศ

พิศคิ้วพระลอราช

ดุจแก้วเกาทัณฑ์

ก่งนา

พิศกรรณงามเพริศแพร้ว

กลกลีบบงกชแก้ว

อีกแก้มปรางทอง

ทำนองนาสิกไท้

เปรียบนา

คือเทพนฤมิตไว้

เปรียบด้วยขอกาม

พระโอษฐ์งามยิ่งแต้ม

ศศือยู่เยียวยะแย้ม

พระโอษฐ์โอ้งามตรู

บารนี

'He is as beautiful as God Indhra coming from heaven to walk on the earth to let human beings see. His body is slim and fragile. His face is as beautiful as the full moon. His eyes are as beautiful as the deer's eyes. His eyebrows are like the bows. His ears are like lotus petals. His cheeks are as nice as gold. His nose is compared to a hook. His lips are like the waning moon. His chin, neck, and shoulder are perfect and smooth. His chest is as nice as a lion's. His arms are like the elephant's trunk. He is so beautiful from head to toe.' [10]

The above extract illustrates how the beauty of men was praised. The prince gained his fame from his beauty and attracted the two princesses with it. The poet was indeed concerned with male beauty as he wrote a long description about the beauty of the prince.

Another example can be found in the classical Thai text entitled Inao, composed by King Rama II in the seventeenth century. The story is about a prince who refuses to marry his arranged bride because he already has a lover. The parents of the bride were angry with her and announced they would give the bride away to anybody. The person who agreed to marry the bride, however, was very ugly. The prince met the bride and fell in love with her because she was very beautiful. The prince did not want her to marry the other man. Thus, the prince had to go through wars and various obstacles before his happy ending of being able to marry the bride from his arranged marriage and also have his former lover as another wife. 
The following extract was cited from the scene where the prince is getting dressed before going to travel to the other city:

$$
\begin{aligned}
& \text { เมื่อนั้น } \\
& \text { ระเด่นมนตรีโอรสา } \\
& \text { ครั้นรุ่งรางสร่างแสงสุริยา } \\
& \text { เสด็จมาสระสรงสรรพางค์ } \\
& \text { ลูบไล้สุคนธาอ่าองค์ } \\
& \text { น้ำมันจันทน์บรรจงทรงพระสาง } \\
& \text { สอดใส่สนับเพลาพลาง } \\
& \text { ทรงภูษาแย่งอย่างลายกระบวน } \\
& \text { ฉลององค์โหมดม่วงร่วงระยับ } \\
& \text { อบอุหรับจับกลิ่นหอมหวน }
\end{aligned}
$$$$
\text { เจียระบาดตาดทองแล่งล้วน }
$$$$
\text { เข็มขัดคาดค่าควรพระนคร }
$$$$
\text { กรองศอสังเวียนวิเชียรช่วง }
$$$$
\text { ทับทรวงสังวาลห้อยสร้อยอ่อน }
$$$$
\text { ตาบกุดั่นประดับซับซ้อน }
$$$$
\text { ทองกรเก้าคู่ชมพูนุช }
$$$$
\text { ธำมรงค์เพชรแพรวแวววับ }
$$$$
\text { กรรเจียกปรับรับทรงมงกุฎ }
$$$$
\text { เหน็บกริชฤทธิรอนสำหรับยุทธ์ }
$$$$
\text { งามดั่งเทพบุตรบทจร }
$$

'The prince is taking a bath.

After that he puts perfume all over his body.

He puts oil onto his hair and combs it neatly.

He puts his trousers on and then a stylish cloth to go with his purple top.

His top has been steamed and perfumed with fragrance from flowers.

His belt is made of gold, the value of it worth the city.

His necklace is made from glittering stone.

He puts on nine pairs of golden bracelets.

His diamond ring glitters brightly.

His ear decoration matches his crown.

He then puts on his sword.

He is as beautiful as a walking angel.'[11]

The above extract reveals that the prince was very neat about dressing up. He used perfume for both his body and his clothes. He is also very conscious about fashion, as his clothes and jewelry have to match. He also used expensive products, as his belt matches the worth of the city, and he wore a diamond ring, which was very shiny. His consciousness and concerns are, thus, the same as those of the metrosexual men in this century.

However, being conscious of the body and beauty was seen not only from the prince. Ordinary men like Khun Paen, the hero of another Thai classical literature Khun Chang Khun Paen, also shows his concern with beauty.
This story is about two men Khun Chang and Khun Paen who fall in love with the same woman called Wanthorng. Eventually, Khun Paen marries Wanthorng and has to go to war with another city. When Khun Paen did not immediately return from war, Khun Chang lies to Wanthorng and says that Khun Paen died in the war and that she has to remarry with someone, otherwise she and all her property will be taken as properties of the state. Wanthorng's mother then forces her to marry Khun Chang. When Khun Paen finally came back from the war, he tried to get Wanthorng back. Wanthorng was moved back and forth between the two men. At the end of the story, the king asked her with whom did she want to live in order to stop the fight between the two men. Wanthorng was hesitant, and the king was angry that she hesitated, so she received a death sentence from the king.

The hero of the story, Khun Paen, was notorious for his flirting. He became a role model to Thai men for being able to get many women with his sweet tongue. The following extract is the scene where he is flirting with Wanthorng. Wanthorng asked him to stop doing flirting, however, otherwise she would break his nail.

$$
\begin{aligned}
& \text { จะหยิกเท่าไรก็ไม่เจ็บ } \\
& \text { ฉวยเล็บมาจะหักให้สะบั้น } \\
& \text { อุยหน่าอย่าทำทีสำคัญ } \\
& \text { ฟาดฟันเอาเถิดไม่น้อยใจ } \\
& \text { ทำเล็บหักเหมือนไม่รักพี่จริงจัง } \\
& \text { ถึงเงินชั่งหารักเท่าเล็บไม่ }
\end{aligned}
$$

'If you're not hurt, I'll break your fingernail.

Oh no, please don't. That's the most important part of me. I will not mind if you kill me, but if you break my nail, I'll take it as you don't love me.

I would never trade my nail for a big amount of money.' [12]

This story was set in the Ayuddhaya Kingdom, over 400 years ago. Khun Paen was a warrior and showed no signs of being gay. He was a symbol of masculine Thai man, but he was also concerned with the beauty of his fingernail. Thus, these extracts confirm the arguments of Whitehead (2002) that masculinities are multiple and plural, differing over time, space, and context, and that they are enmeshed with variables such as race, ethnicity, class, and age.

\section{CONCLUSION}

Nowadays, a metrosexual man is seen as a new type of men in this century, and he does not fit into the category of being masculine. However, as this article demonstrates, masculinities vary over time and setting. In Thai literature, which is a reflection of Thai society, metrosexual men are illustrated as being accepted in the ancient society as 'normal.' Therefore, male bodies and beauty have been related since the olden days, and a metrosexual man is, thus, not a 'new type' of men, as he existed many centuries ago. In conclusion, men, as we have seen from these classical texts, also like to be beautiful too. 


\section{ACKNOWLEDGMENT}

This research was funded by the Research and Technology Transfer Affairs Division, Khon Kaen University.

\section{REFERENCES}

[1] S. Whitehead, Men and Masculinities. Cambridge: Polity Press, 2010

[2] D. Richardson and V. Robinson, (ed.). Introducing Gender and Women's Studies, Hampshire: Palgrave MacMillan, 2008.

[3] K. Woodward, Gendered Bodies: Gendered Lives, Hamshire: Palgrave Macmillan, 2008. pp. 75.

[4] M. M. A. Ghaill, (ed.) Understanding Masculinities, Buckingham: Open University Press, 1996.

[5] M. Simpson, Meet the Metrosexual, New York, 2002.

[6] T. Edwards, Cultural Masculinities, London: Routledge, 2006.

[7] M. Abbott, Masculine and Feminine, New York: Mac Graw Hill, 1992.

[8] M. Simpson, Here Come the Mirror Men, The Independent, November 15, 1994.

[9] Department of Fine Arts, Lilit Pralor, Bangkok: Bannakhan, 1983, pp. $5-6$.

[10] Inao, Bangkok: Bannakhan,1971, pp. 37

[11] Khun Chang Khun Paen, Bangkok: Bannakhan.1967, pp. 98.

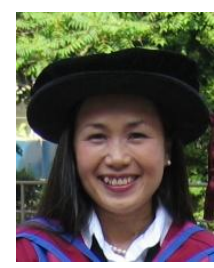

Orathai Piayura received a Bachelor of Arts degree in English from Khon Kaen University, Thailand in 1994, a Master of Arts in English Language in Literary Studies from the University of Nottingham, England in 1995, and a Doctorate of Philosophy (Gender Studies and Thai Literature) from the University of London, England in 2006. She is an Assistant Professor of Languages and Literature in the Thai Department, Faculty of Humanities and Social Sciences, Khon Kaen University. From 2005-2006, she was an Assistant Dean for International and Special Affairs Faculty of Humanities and Social Sciences, Khon Kaen University. Additionally, she used to work as a Tutor of Thai and Lao at SOAS (The School of Oriental and African Studies) Language Center, University of London, from 1999-2005 and was a Language Trainer for the Foreign and Commonwealth Office (FCO) in London from 2003-2005. Her PhD thesis was concerned with Gender and Sexualities in Thai Erotic Literature and her MA thesis was entitled Feminism in Thai and English Short Stories: A Comparison. She has written many articles in the field of gender and sexualities in Thai literature and society. For instance, [1] Orathai Panya. 2005. Traditions of Eroticism in Thai Literature and the Contribution of Sujindaa Khantayaalongkot. Journal of Mekong Societies. Khon Kaen: Klangnanawittaya. [2] Orathai Piayura. 2010. Strength, Dominance, and Sexualities: The Presentation of Masculinities in Thai Erotic Literature. Humanities and Social Sciences Journal, Khon Kaen University. Khon Kaen: Klangnanawittaya. Vol. 3. pp. 34-39. [3] Orathai Piayura. 2010. Women, Sexuality, and Political Achievement in Thai Society and Thai Literature. Asian Review, Chulalongkorn University. Vol. 23. pp. 53-70. 